\title{
ANALISIS TERHADAP PEMIKIRAN ALI SYARI'ATI TENTANG KONSEP HUMANISME ISLAM
}

\author{
Oleh: \\ Asep Wildan \\ Aqidah dan Filsafat Islam, Ushuluddin \\ UIN Sunan Gunung Djati Bandung
}

\begin{abstract}
Abstrak
Penelitian ini bertolak dari pemikiran bahwa peradaban saat ini sangatlah kebaratbaratan, dengan kata lain Eropa menjadi acuan, humanisme Eropa menjadi dasar dari peradaban saat ini. Padahal, humanisme Eropa cenderung mengedepankan intelejensi dan kehendak bebas dari manusia yang pada akhirnya mendorong manusia untuk mengeksploitasi alam sedemikian rupa. Dengan kata lain mendorong manusia untuk berbuat kerusakan di muka bumi. Ali Syari'ati sendiri merupakan seorang tokoh dari Iran yang terkenal dengan gayanya yang khas, memaparkan hampir semua teori humanisme barat berikut kelemahan-kelemahannya, dan menghadapkan semua teori itu dengan pandangan dunia Islam. Yang juga mengajukan Islam sebagai agama yang mampu menjawab seluruh tantangan kehidupan modern. Dalam menghimpun data, baik primer juga sekunder, penulis menggunakan teknik studi kepustakaan serta dokumentasi. Dengan mengumpulkan semua buku dan literatur karya Ali Syari'ati yang telah di terjemahkan ke dalam bahasa Indonesia. Di kumpulkan juga buku dan literatur mengenai topik dan Ali Syari'ati yang ada relevansinya dengan masalah yang dibahas. Hasil analisis menunjukkan bahwa (1) Humanisme menurut Ali Syari'ati adalah aliran filsafat yang menyatakan bahwa tujuan pokok yang dimilikinya adalah untuk keselamatan dan kesempurnaan manusia. Humanisme memandang manusia sebagai makhluk mulia, dan prinsip-prinsip yang disarankannya didasarkan atas pemenuhan kebutuhan-kebutuhan pokok yang bisa membentuk manusia menjadi lebih baik. (2) Menurut Ali Syari'ati, pernyataan humanisme dalam Islam adalah yang paling dalam dan paling maju, mengacu pada kisah kejadian Adam dalam Al-Qur'an. Islam mengajarkan bahwa di hadirat Allah manusia bukanlah makhluk yang rendah, karena ia adalah rekan Allah, teman-Nya, pendukung amanah-Nya di bumi. Manusia menikmati afinitasnya dengan Allah, menerima pelajaran dari-Nya, dan telah menyaksikan betapa semua malaikat Allah jatuh bersujud kepada-Nya.
\end{abstract}


Kata Kunci: Pemikiran Ali Syari'ati, Konsep Humanisme Islam

\begin{abstract}
This research starts from the idea that today's civilization is very westernized, in other words Europe is a reference, European humanism is the basis of today's civilization. In fact, European humanism tends to prioritize intelligence and free will from humans which in turn encourages humans to exploit nature in such a way. In other words encourage people to do damage on the face of the earth. Ali Syari'ati himself is a figure from Iran who is famous for his distinctive style, describing almost all western humanism theories and their weaknesses, and confronting all those theories with the Islamic worldview. Those who also propose Islam as a religion are able to answer all the challenges of modern life. In collecting data, both primary and secondary, the author uses library research techniques and documentation. By collecting all the books and literature by Ali Syari'ati which have been translated into Indonesian. Also collected books and literature on the topic and Ali Syari'ati who have relevance to the issues discussed. The results of the analysis show that (1) Humanism according to Ali Shari'ati is a school of philosophy which states that the main purpose it has is for human safety and perfection. Humanism views human beings as noble beings, and the principles suggested by them are based on fulfilling basic needs that can shape human beings for the better. (2) According to Ali Syari'ati, the statement of humanism in Islam is the deepest and most advanced, referring to the story of the events of Adam in the Qur'an. Islam teaches that in the presence of God human beings are not inferior beings, because he is a partner of Allah, His friend, supporting His message on earth. Humans enjoy their affinity with God, accept lessons from Him, and have witnessed how all the angels of God fell to Him.
\end{abstract}

Keywords: Thought of Ali Shari'ati, Concept of Islamic Humanism

\title{
A. Pendahulua
}

Aliran eksistensialisme, merupakan salah satu aliran filsafat yang membicarakan tentang Manusia. Pembicaraan ini misalnya bisa ditemukan dalam pemikiran Nietzsche. Ia mengungkapkan bahwa manusia dan binatang itu secarapa prinsip tidak terbedakan satu sama lain. Kekuatan (Kraf) dan proses (Ernäherungs-Vorgang) merupakan daya yang terhimpun di dalam kedua mahluk tadi. Akan tetapi yang menjadi khas pada manusia adalah daya untuk mencapai tujuan bagi dirinya sendiri dan potensi untuk 
melampaui diri. ${ }^{1}$ Sedangkan dalam pendapat Ftihjof Schuon, intelejensi, perasaan dan kehendak, merupakan bagian esensial di dalam diri manusia. Cinta, rasa takut serta pengetahuan pun bisa kita sebut bagian dari dimensi manusia. $^{2}$

Pada zaman ini, manusia menunjukan dirinya sebagai sosok mahluk yang telah mengeksploitasi alam. Sikap itu sendiri muncul dari kehendak dan intelegensi yang dimilikinya. Dua dimensi inilah yang membuat manusia memposisikan dirinya sebagai penguasa alam. Sikap ini berimplikasi pada kerusakan alam seperti: pemanasan global, ozon yang rusak, lelehnya gununggunung es, dan lain semacamnya. Sikap ini juga bisa disebut sebagai representasi dari cara manusia memaknai dunia, dan bagaimana manusia mengekspresikan kebutuhannya.

Kesadaran Eropa sendiri terepresentasi dari humanisme radikal yang menganggap bahwa nilai kemanusiaan terletak pada kebebasan dan rasionya. Dengan daya-daya inilah kebebasan dan realisasi rasio ini diwujudkan. ${ }^{3}$ Akan tetapi, sebagaimana disebutkan sebelumnya, bahwa manusia tak hanya memiliki daya-daya itu, karena manusia pun memiliki intelejensi, perasaan, (cinta dan kelembutan). Selain itu, Karen Armstrong mengatakan, bahwa manusia letak perbedaan antara manusia dengan mahluk lainnya terletk pada cinta. Bahkan, kepedulian dan perasaan merupakan hal yang esensial bagi manusia, hal ini terjadi dikarenakan efek dari hasil evolusi otak manusia. ${ }^{4}$

Kepedulian itu sendiri sebenarnya dijamin atau dijaga oleh Etika. Bagi Franz Magnis-Suseno, etika itu sendiri lahir akibat dari kebobrokan moralitas yang terjadi pada kultur Yunani sekitar 2500 tahun yang lalu. Para filsuf Yunani pada saat itu merasa bahwa distingsi baik-buruk, norma-norma dasar masyarakat mesti dicurigai dan dipertanyakan kembali. ${ }^{5}$

\footnotetext{
${ }^{1}$ St. Sunardi, “NIETZSCHE”, (LKiS: Yogyakarta, 2009), Cet. IV, hlm. 72.

${ }^{2}$ Frithjof Schuon, Transfigurasi Manusia, (QALAM: Yogyakarta, 2002), Cet. I, hlm. 73.

${ }^{3}$ Kazuo Shimogaki, KIRI ISLAM Antara Modernisme dan Postmodernisme, (LKiS: Yogyakarta, 2007), Cet. VII, hlm. 142.

${ }^{4}$ Karen Armstrong, Compassion: 12 langkah menuju hidup berbelas kasih, (Mizan: Bandung, 2012), Cet. 1, hlm. 26.

${ }^{5}$ Franz Magnis-Suseno, ETIKA DASAR Masalah-masalah pokok filsafat moral, (KANISIUS: Yogyakarta, 2010), Cet. 21, Hlm. 15.
} 
Hukum itu sendiri lahir dari prinsip etika. Lalu, dari hukum itu sendiri bentuk kesewenang-wenangan manusia kemudian dibatasi, demi kebebasan, hak dan kepentingan bersama. Meskipun di sisi lain, hukum sendiri menyuguhkan ancaman bagi siapa saja yang melanggar aturan normatif yang ditetapkan, dengan cara memberi sebuah hukuman. ${ }^{6}$

Institusi yang mengatur norma-norma dasar yang dijalani manusia bisa ditemukan di dalam Agama. Akan tetapi, bentuk pengaturan norma di dalam agama hanya bisa dijamin oleh Tuhan. Karena Tuhan bagi agama merupakan dasar dan pokok, sekaligus sebagai tujuan dan asal dari nasib manusia itu sendiri. ${ }^{?}$

Islam sendiri sebagai agama, hadir dengan menyuguhkan fondasi dari nilai-nilai bagi manusia. Fondasi itu tentu dijamin oleh Tuhan dan juga kitab Suci, yakni Al-Qur'an, demi orientasi hari akhir. ${ }^{8}$

Al-Qur'an sendiri memiliki gambaran tentang manusia. Di dalamnya manusia digambarkan sebagai mahluk yang memiliki dimensi, yakn idimensi terpuji dan tercela, dan hal ini ditegaskan di dalam berbagai ayat. Namun, dengan hal ini, al-Qur'an memaksudkan bahwa manusia dapat memilih, apakah ia akan menjadi manusia yang terpuji atau tercela. Dan manusia ditentukan oleh al-Qur'an untuk memiliki kewajiban (taklif) memilih salah satu di antara dua kecenderungan tersebut. ${ }^{9}$

Dalam konteks status kekurangan dan kemuliaan manusia, Allah sendiri menggambarkannya dalam Q.S Al-Anam: 165, Q.S Al-Isra: 70, AlBaqarah: 30, Q.S At-Tin: 4 dan Q.S Al-Ahzab: 72. Dan di dalam ayat-ayat itulah Allah telah menegaskan, bahwa manusia itu berbeda dan ia lebih mulia dibanding mahluk-mahluk lain ciptaan-Nya. Akan tetapi di sisi lain, manusia pun memiliki kekurangan. Namun justru dengan dua dimensi itulah manusia dipercaya sebagai wakil Tuhan di bumi ini. ${ }^{10}$ Kemudian, dalam salah

\footnotetext{
${ }^{6}$ Ibid. hlm. 39.

${ }^{7}$ Marcel A. Boisard, Op. Cit.

${ }^{8}$ Ibid.

${ }^{9}$ Abbas Mahmud Al-Aqqad, Manusia Diungkap Qur'An, (Pustaka Firdaus: Jakarta, 1986), Cet. I, hlm. 11.

${ }^{10}$ Muhammad Iqbal, Rekonstruksi Pemikiran Agama dalam Islam, (Jalasutra: Yogyakarta, 2008), Cet. 2, hlm. 112.
} 
satu ayat di atas dijelaskan, bahwa manusia adalah mahluk yang berani untuk mengemban tugas sebagai khalifah, di mana mahluk lain menolak tugas tersebut. Sebagai mahluk yang mengemban misi kepemimpinan, manusia pun tidak luput dari kecenderungan untuk melakukan kerusakan di muka bumi ini.

Namun, dengan segala kelebihan dan kekurangannya, pembicaraan mengenai manusia tak pernah selesai untuk dibicarakan. Dan pembicaraan tentang manusia ini bisa ditemukan dalam pemikiran Ali Syariati. Dalam hal ini, Syariati mengklaim bahwa peradaban manusia serta pemujaan atas manusia didasarkan atas sebuah keyakinan atas humanisme. ${ }^{11}$ Karena humanisme merupakan dasar dari peradaban manusia, sebagaimana klaim Syariati, maka dari itu penulis berkehendak untuk melakukan penelitian atas konsep humanisme itu sendiri.

Namun, untuk menspesifikan penelitan ini, penulis membatasi kajian tentang humanisme ini pada pemikiran yang ada di dunia Islam, dan salah satu pemikir Islam yang dipilih penulis dalam penelitian ini adalah Ali Syariati.

Alasannya, karena peradaban hari ini didasarkan pada humanisme ala Eropa, yang justru dari humanisme ala Eropa itulah lahir segala bentuk kerusakan dan eksploitasi. Kecenderungan negatif itu sendiri lahir, karena humanisme Eropa itu sendiri terlalalu menekankan pada aspek rasionalitas/intelegensi dan kehendak manusia, dan dua hal inilah yang menyebabkan kerusakan terjadi di muka bumi.

Islam sendiri dihadirkan oleh Syariati, sebagai agama yang mampu menjawab keterbatasan-keterbatasan dan kekurangan yang ada pada dunia modern. Syariati sendiri merupakan sosok pemikir Iran yang kredibel dalam menjelaskan humanisme Barat beserta kelemahan-kelemahannya.

\footnotetext{
${ }^{11}$ Ali Syari'ati, Op. Cit.
} 


\section{A. Hasil dan Pembahan}

\section{Kritik Ali Syari'ati Terhadap Humanisme Barat}

Ali Syari'ati tidak pernah secara sistematis menunjukkan sikap anti barat. ${ }^{12}$ Ada semacam hubungan cinta-benci dari Ali Syari'ati terhadap pemikiran Barat. Pemikirannya yang mengkritik filsafat Barat tidak terhimpun dalam beberapa buku utuh, tetapi tersebar dalam beberapa kumpulan tulisan dan ceramah. Diantaranya Marxism and Other Western Fallacies, Man and Islam, What is to be Done, dan Doa. Kritiknya terhadap filsafat Barat juga terdapat dalam Kavir (Salt Desert) dan Islamsyinasi (Islamologi)..$^{13}$

Ali Syari'ati mengatakan bahwa keterasingan manusia bisa terjadi di dalam dua ranah, yakni sistem masyarakat dan ideologi. Kedua ranah inilah yang membawa manusia menjauh dari jati dirinya. Jati diri itu sendiri ditemukan di luar ranah materialitas manusia itu sendiri. ${ }^{14}$

Homo eceonomicus, merupakan basis dari dua sistem ideologi masyarakat yang bertentangan pada masa modern, ideologi tersebut ialah komunisme dan kapitalisme. Meskipun secara faktual, kapitalisme lah yang menjadi dominan. Anggapan bahwa manusia adalah homo economicus ini serasi dengan pernyataan Francis Bacon yang berkata, bahwa masyarakat industrial adalah masyarakat yang meninggalkan ilmu untuk mencari kebenaran, dan mengarah pada pencarian kekuasaan”. ${ }^{15}$

Logika yang bekerja di dalam masyarakat industrial ialah logika konsumer, yang mana logika ini hanya mungkin hadir jika kebutuhankebutuhan material diciptakan setiap hari, dan penciptaan ini bekerja secara massif di tengah masyarakat. Teknologi, yang merupakan tangan kanan dari

\footnotetext{
${ }_{12}$ Robert D. Lee, Mencari Islam Autentik: Dari Nalar Puitis Iqbal Hingga Nalar Kritis Arkoun, (Mizan: Bandung. 2000), Cet. II, hlm. 138.

${ }^{13}$ Ekky Malaky, Ali Syari'ati Filosof Etika dan Arsitek Iran Modern, (TERAJU: Jakarta, 2004), Cet. I, hlm. 43.

${ }^{14}$ Ali Syari'ati, Humanisme antara Islam dan Madzhab Barat, (Pustaka Hidayah: Bandung, 1996), Cet. II, hlm. 57.

${ }^{15} \mathrm{Ibid}$.
} 
masyarakat industri alih-alih menjadi pembebas kerja manusia, malah justru menjerat manusia itu sendiri. ${ }^{16}$

Nilai-nilai tradisional yang mestinya hadir di tengah masyarakat, pada akhirnya mesti tergerus oleh gelombang logika masyarakat industrial ini. Masyarakat pada akhirnya tenggelam sepenuhnya di dalam kepentingan untuk mengejar kebutuhan-kebutuhan material belaka. ${ }^{17}$

Tetapi kebobrokan ini tidak hanya dialami oleh masyarakat kapitalis saja, di dalam masyarakat komunis pun mengalami kecenderungan kerusakan moral yang sama. ${ }^{18}$ Meskipun masyarakat komunis memiliki perbedaan tersendiri atas masyarakat kapitalis, namun dalam beberapa hal tertentu terdapat kesamaan-kesamaan dalam ranah psikologi sosial, filsafat hidup, psikologi sosial dan tabiat kemanusiaan. ${ }^{19}$ Kesamaan lain misalnya, bisa dilihat dalam aspek konsumer itu sendiri. Jika dalam masyarakat kapitalisme konsumerisme dialami oleh individu, di dalam masyarakat komunis konsumerisme itu sendiri dialami secara kolektif. ${ }^{20}$

Kerusakan manusia modern pun bisa dilacak dalam ideologi. Menurut Ali Syariati, ideologi berfungsi sebagai pengabur nilai-nilai bawaan yang ada di dalam diri manusia; dan humanisme merupakan bagian dari ideologi tersebut. ${ }^{21}$

Historisisme meyakini bahwa perjalanan sejarah umat manusia ditentukan sepenuhnya oleh proses-proses material. Proses material determinatif ini tentu saja tidak bisa diubah, dengan demikian manusia menjadi pasif di hadapannya. ${ }^{22}$

Biologisme (paham yang berkenaan dengan hukum-hukum kehidupan alam) menganggap bahwa binatang dan manusia tidak memiliki perbedaan esensial. Satu-satunya perasangka baiknya adalah anggapannya bahwa

\footnotetext{
${ }^{16}$ Ali Syari'ati, Kritik Islam atas Marxisme dan Sesat-pikir Barat Lainnya, (Mizan: Bandung, 1983), Cet. I, hlm. 78.

${ }^{17} \mathrm{Ibid}$.

${ }^{18}$ Ali Syari'ati, Op. Cit. hlm. 58

${ }^{19}$ Ali Syari'ati, Kritik Islam atas Marxisme dan Sesat-pikir Barat Lainnya, Op.Cit. hlm. 79

${ }^{20}$ Ali Syari'ati, Loc. Cit.

${ }^{21}$ Ibid. hlm. 59

${ }^{22}$ Ali Syari'ati, Op. Cit. hlm. 80
} 
manusia adalah mata rantai terakhir dalam silsilah evolusi makhluk hidup. Kalau tidak maka seluruh fenomena mental dan spiritual manusia yang khas itu tak lebih dari sekedar naluri-naluri alamiah dalam bentuk respons-respons syaraf. $^{23}$

Sosiologisme memandang manusia sebagai sayuran yang tumbuh dalam taman lingkungan sosialnya; jadi memerlukan iklim dan tanah yang layak. Sosiologisme menganggap bahwa panen manusia akan hanya apabila taman itu diubah. Dan sebagaimana kasus di muka, proses ini berlangsung menurut hokum ilmiah di luar kemungkinan campur tangan manusia - hukumhukum yang mengatur tindakan-tindakan manusia dan bahkan kepribadiannya. $^{24}$

Pada dasarnya, sosiologisme me-mandang manusia sebagai suatu bangunan. Sebab, manusia merupakan komunitas yang terdiri dari satuansatuan manusia, dan tak lebih dari itu. Kesimpulannya, manusia muncul dalam bentuk produsen yang menciptakan produk-produk materiil. Dan sepanjang alat-alat produksi adalah sesuatu yang ditentukan oleh bentuk produk-produk, maka pada analisis akhirnya humanisme dan Marxisme muncul dari pandangan bahwa manusia itu hanyalah alat semata. Artinya, itu adalah wadah bagi humanisme dan eksistensi-alisme. Berbeda dengan Islam yang mengatakan bahwa manusia itu anak-cucu Adam, Marxisme mengatakannya sebagai "anak-cucu teknologi" 25

Ali Syari'ati berpendapat, jika terhadap aliran-aliran di atas ditambahkan materialisme dan naturalisme yang menganggap manusia sebagai benda atau binatang yang bersifat biologis, maka kita menemukan malapetaka lain dalam aspek keyakinan pada zaman modern ini. ${ }^{26}$ Dalam konstelasi seperti ini, Marxisme mempunyai pandangan yang kontradiktif. Dari sisi bahwa ia adalah materialism, dan berdasar itu pula, maka ia tidak mungkin memandang manusia sebagai suatu "perwujudan" kecuali sekadar unsur yang berada dalam batas-batas materi. Pada sisi lain, Marx pernah menulis sepucuk surat kepada Engels, sesudah mengkaji karya Darwin, yang

\footnotetext{
${ }^{23}$ Ali Syari'ati, Humanisme antara Islam dan Madzhab Barat, Loc. Cit.

${ }^{24}$ Ali Syari'ati, Op. Cit. hlm. 81.

${ }^{25}$ Ali Syari'ati, Op. Cit. hlm. 60

${ }^{26}$ Ibid.
} 
mengatakan, "Saya menerima teori ini sebagai suatu kaidah biologis bagi filsafat sejarah". ${ }^{27}$

Kaitannya dengan Marxisme, posisi Syari'ati tidak hanya mengkritiknya. Ia juga terpengaruh oleh Marxisme, hanya saja ajaran ini diambil untuk beberapa ceramahnya secara selektif dan ketat. ${ }^{28}$ Marxisme hadir sebagai antitesa dari ideologi kapitalisme. Dengan ini, Marxisme menentang konsep tentang kepemilikan privat alat produksi, akumulasi modal, dan lain-lain. namun, yang paling penting ialah penolakannya terhadap hakikat manusia di dalam konteks sistem produksi dan kerjas sosial. $^{29}$

Tujuan dari revolusi Marxisme ialah menciptakan tatanan diktatorproletariat, yang mana menggantikan masyarakat yang dilandaskan oleh kebebasan. Dengan demikian, masyarakat di dalam tatanan ini dikontrol sepenuhnya dari atas, yakni birokrasi proletariat, sebagai ganti dari pola birokrasi borjuistik.

Martabat manusia dalam "Birokrasi dengan pemerintahan yang tersentralisasi" menggantikan pembebasan manusia dari "Polarisasi manusia berdasarkan kekhususannya", yang diwujudkan oleh kekejaman kapitalisme - suatu polarisasi kerja berdasarkan spesialisasi. Bukannya menciptakan manusia yang bebas dari "lembaga-lembaga administratif-ekonomi kapitalis", namun yang hadir malah "masyarakat yang diorganisasi secara ketat". Bukannya hilang "taklid dan penyembahan terhadap gereja", malah yang hadir adalah taklid dan menyembah kepada "Biro ideologi". Alih-alih "mengagungkan kaidah-kaidah", yang muncul adalah "pengingkaran hak pribadi dalam sejarah". ${ }^{30}$

Dari segi ideologi, adalah runtuhnya humanisme dalam materialismeekonomi yang rendah. Manusia yang memiliki kebebasan dan kehendak, yang memiliki kesadaran dan jati diri, yang mempunyai martabat tinggi dan menguasai alam, sekarang menjadi bulan-bulanan dalam permainan ngawur

\footnotetext{
${ }^{27}$ Ibid.

${ }^{28}$ Ekky Malaky, Op. Cit, hlm. 46

${ }^{29}$ Ali Syari'ati, Op. Cit. hlm. 69.

${ }^{30}$ Ibid. hlm. 70.
} 
dialektika historis yang deterministik, dan makhluk tanpa kehendak di tangan dialektika materialisme yang menguasai eksistensi manusia. ${ }^{31}$

Pada masyarakat kapitalis, manusia diposisikan sebagai mahluk tanpa ikatan apapun. Sedangkan kondisi "terbelenggu dan terikat" merupakan karakter dari masyarakat Marxis. Pada sistem kapitalis, masyarakat berada dalam kondisi tertitpu, sedang dalam sistem Marxis, manusia hadir dalam kondisi yang dibentuk. ${ }^{32}$ Tetapi, bagi Ali Syari'ati, setidaknya kaum dalam Marxsisme memiliki "kebenaran”. Unsur yang benar itu ialah unsur melawan penindasan, yang mana sesuai dengan implikasi keberimanan kepada Tuhan. ${ }^{33}$

Pada eksistensialisme Ali Syari'ati memiliki dua sikap, yakni mengkritik dan memuji, hal ini nampak dari cara Syariati berhadapan dengan Camus dan Sartre. ${ }^{34}$ Eksistensialisme menjadikan manusia sebagai Tuhan. Hal ini berbeda dengan kapitalisme yang menganggap manusia hanya sebagai mahluk ekonomi; beda dengan Katolokisme yang menganggap manusia sebagai mahluk yang hadir sebagai permaianan dari kemauan Tuhan; berbeda dengan materialisme dialektika yang menganggap manusia merupakan efek deterministik dari alat produksi; dan berbeda dengan Marxsisme yang menganggap manusia sebagai objek organis. Eksistensialisme menegaskan: "Semua makhluk dunia ini menyadari eksistensinya setelah esensi mereka ditentukan, kecuali manusia, yang menciptakan esensinya lebih dahulu daripada eksistensinya". ${ }^{35}$

Jean Paul Sartre, memiliki anggapan dualis terhadap manusia, yakni dimensi sifat bawaan alamiah dan dimensi sifat bawaan manusia. Sebenarnya, dualisme ini bisa ditemukan pada Zoroaster, dualisme Mani, bahkan di dalam Islam sekalipun. ${ }^{36}$ Sartre sendiri tidak hendak membangun eksistensialismenya di bawah semangat keagamaan, namun Sartre ingin meletakan eksistensialisme agar senada dengan materialisme yang ada pada

\footnotetext{
${ }^{31} \mathrm{Ibid}$.

${ }^{32}$ Ibid.

${ }^{33}$ Ekky Malaky, Op. Cit, hlm. 49.

${ }^{34}$ Ibid. hlm. 50.

${ }^{35}$ Ali Syari'ati,Kritik Islam atas Marxisme dan Sesat-pikir Barat Lainnya, Op.Cit hlm. 96

${ }^{36} \mathrm{Ibid}$. hlm. 97.
} 
Marxsime. $^{37}$ Hal ini merupakan penurunan yang terjadi di mana pada mulanya manusia berada pada titik manusia-tuhan (god-man) ke dalam jurang keputusasaan dan kecemasan. ${ }^{38}$

Menurut Ali Syari'ati, kelemahan konsep Sartre itu ada pada anggapannya tentang manusia yang menciptakan dirinya melalaui kerja, alihalih mendasarkan konsepsi manusia sebagai entitas yang utuh dan padu. ${ }^{39}$ Dan kerja, yang dilandasi oleh kebebasan ini, tidak dideterminasi oleh apapun kecuali oleh dirinya sendiri, entah itu bersifat negatif atau positif. ${ }^{40}$

\section{Analisis Terhadap Pemikiran Ali Syari'ati Tentang Humanisme Islam}

a. Bagaimana konsep humanisme menurut Ali Syari'ati?

Di tengah berbagai macam pengertian dan pemahaman mengenai manusia, entah itu dari aliran filsafat, agama maupun dalam konteks ilmiah, kita dapat mengambil titik temu dalam memahami manusia. Kumpulan berbagai prinsip dasar dari unsur-unsur manusia yang diyakini bersama hadir dalam humanisme. ${ }^{41}$

Bagi Ali Syariati, tujuan humanisme ialah membawa manusia pada kesempurnaan dan keselamatan manusia. Kebutuhan-kebutuhan yang dimiliki manusia dianggap mesti dipenuhi di dalam humanisme. ${ }^{42}$

Kurang lebih ada empat aliran yang mewakili spirit humanisme, di antaranya ialah: agama, eksistensialisme, liberalisme Barat, dan Marxisme. ${ }^{43}$

Liberalisme Barat sendiri memiliki akar tradisi historis yang bermula dari peradaban Yunani Kuno, dan liberalisme itu sendiri hadir sebagai puncak atau titik modern kematangan dari kebudayaan tersebut. ${ }^{44}$ Humanisme Barat itu sendiri didasarkan pada pada kerangka mitologi

\footnotetext{
${ }^{37}$ Ali Syari'ati, Humanisme antara Islam dan Madzhab Barat, Op. Cit. hlm. 74.

${ }^{38}$ Ali Syari'ati,Kritik Islam atas Marxisme dan Sesat-pikir Barat Lainnya, Op.Cit hlm. 97

${ }^{39}$ Ali Syari'ati, Humanisme antara Islam dan Madzhab Barat, Op. Cit. hlm. 75.

${ }^{40}$ Ibid.

${ }^{41}$ Ibid. hlm. 39.

${ }^{42}$ Ibid.

${ }^{43}$ Ali Syari'ati, Kritik Islam atas Marxisme dan Sesat-pikir Barat Lainnya, Op.Cit, hlm.52

${ }^{44}$ Ali Syari'ati, Humanisme antara Islam dan Madzhab Barat, Op. Cit. hlm. 40.
} 
Yunani Kuno, yang mendasarkan dirinya pada konsepsi pertentangan dan pertarungan antara manusia dengan dewa. Manusia dan dewa dianggap bertentangan satu sama lain, di mana dewa di sana berusaha menundukan manusia. Dewa-dewa Yunani Kuno khawatir dengan kebebasan, kemerdekaan dan kehendak dari manusia itu sendiri. Dan karena kehendak dan kebebasannya itulah, yang membawa manusia pada pemberontakan, membawa manusia pada hukuman-hukuman para dewa. ${ }^{45}$

Melalui kekuatan dan kesadaran yang selalu meningkat, manusia secara terus-menerus berusaha menyelamatkan dirinya dari sosok dewa. Dan jalan satu-satunya agar manusia bisa bebas dari belenggu hukuman para dewa ialah dengan cara memberontak dan melawan pada kekuasaan para dewa yang kejam. Manusia mesti berhasil untuk menggeser tahta yang dulunya diduduki oleh dewa. ${ }^{46}$

Wujud pencapaian kesempurnaan diri manusia itu, bagi Humanisme Yunani, hanya mungkin diwujudkan dengan cara mengingkari eksistensi dari Tuhan itu sendiri. Ketika eksistensi Tuhan diingkari, maka segala patokan kebenaran diletakan pada diri manusia. ${ }^{47}$

Dengan demikian, Humanisme hadir dengan wajahnya yang materialis. Materialisme ini hadir di dalam liberalisasi sains, Marxisme, dan peradaban Borjuis Barat. Kemudian, dengan materialisme inilah, humanisme jelas bertentangan dengan teisme. Pertarungannya dengan demikian terjadi dengan yang membela "langit" dengan yang membela "bumi"; dan humanisme memiliki posisi yang terakhir. Di sebrang itu terdapat para pendeta, yang dianggap sebagai wakil dari Tuhan atau dunia Langit. Dan kaum pendeta ini menegaskan bahwa kebahagiaan manusia hanya mungkin dicapai jika seseorang melakukan taklid buta kepada mereka. $^{48}$

Dalam Katholik zaman pertengahan, bahwa hanya dengan peniadaan sifat yang murni manusiawi sajalah manusia akan mencapai Tuhan; jadi, ia

\footnotetext{
${ }^{45}$ Ibid.

${ }^{46}$ Ibid.

${ }^{47}$ Ibid. hlm. 42.

${ }^{48}$ Ibid.
} 
menjadi objek kesenangan Tuhan. Alangkah miripnya Tuhan Kristen dengan Zeus. Jadi, kalau kita berbicara mengenai humanisme modern Eropa sebagai kelanjutan dari humanisme Yunani, kita bisa juga berbicara mengenai Celestialisme (penjasadan) dalam Kristen Masa Pertengahan sebagai kelanjutan dari Celestialisme mitos Yunani. Di Barat, baik di zaman pertengahan maupun modern, setiap orang mengambil inspirasinya dari Yunani. Dengan demikian kebudayaan Barat lahir dari dua pertentangan di atas. $^{49}$

Sekitar abad 18 dan awal abad 19, pada keterangan yang dipublikasikan sekitar tahun 1800, kaum radikalis humanisme modern, mereka menegaskan, "singkirkan Tuhan dari kaidah moral, dan gantikan dengan kata hati, sebab manusia adalah makhluk yang punya kata hati yang bersifat moral bawaan." Pernyataan ini (yang didasarkan pada conscience morale) diyakini lahir dari hakikat diri manusia itu sendiri. ${ }^{50}$

Maka humanisme modern, dengan semuanya itu menjadi landasan dari liberalisme Barat-Borjuis, yang memandang bahwa manusia memiliki segala nilai-nilai mulia yang ada di dalam dirinya. Tepat pada posisi itulah, humanisme modern bertolak belakang dengan metafisika dan naturalisme. ${ }^{51}$

Marxisme, sendiri yang terepresentasi dalam Marx, terbagi ke dalam dua bagian: Pertama, penolak sistem kapitalis; kedua Marx sebagai perancang sosialis-komunismenya. ${ }^{52}$ Pada sisi yang kedua inilah, Marx hadir sebagai seorang politisi dengan kacamata kritik ekonomi-politiknya, yang revolusioner hadir untuk menentang habis-habisan kekuasan politis. ${ }^{53}$

Kesadaran kritis ini tentu lahir dari anggapan Marx, bahwa kapitalisme telah menghancurkan nilai kemanusiaan itu sendiri. "Manusia yang bergairah dan sadar, jujur dan bebas, kenal akan dirinya dan memiliki keutamaan-keutamaan moral" kemudian teralienasi oleh sistem yang zalim yang bernama kapitalisme. Lalu Marx mengatakan, "Kerja adalah jati diri manusia yang dipandang oleh kapitalisme sebagai tambang (kekayaan)

\footnotetext{
${ }^{49}$ Ali Syari'ati, Kritik Islam atas Marxisme dan Sesat-pikir Barat Lainnya, Op.Cit, hlm. 58.

${ }^{50}$ Ali Syari'ati, Humanisme antara Islam dan Madzhab Barat, Op. Cit. hlm. 45.

${ }^{51}$ Ibid. hlm. 45-46.

${ }^{52} \mathrm{Ibid}$.

${ }^{53}$ Ali Syari'ati, Kritik Islam atas Marxisme dan Sesat-pikir Barat Lainnya, Op.Cit, hlm. 62.
} 
materi, dinilai dengan uang, dan pada gilirannya manusia disebut sebagai 'budak perutnya'. 54

Di sebrang yang lain, eksistensialisme menjelaskan bahwa manusia adalah mahluk yang terlempar ke dunia dengan sendirinya, tanpa determinasi alam maupun Tuhan. Dengan kehadiran yang terlempar inilah, manusia kemudian menciptakan dirinya berdasarkan kehendaknya sendiri. ${ }^{55}$

Pada agama-agama Timur, kemanusiaan memiliki relasi yang unik dengan Zat Absolut semesta alam. Dalam agama Zoroaster, manusia diyakini sebagai teman Ahuramazda, dan bahkan sekutunya dalam perjuangan penciptaan yang agung demi kemenangan kebaikan atas Arga Mainyu dan pasukannya. Dalam agama-agama mistik yang berdasar pada kesatuan eksistensi (unity of existence) - dan terutama sekali Hinduisme - Tuhan, umat manusia dan cinta, semua tampak seperti terikat dalam semacam makar untuk menciptakan kembali dunia eksistensi. Manusia dan Tuhan dalam agama ini begitu berbaur, sehingga tidak dapat dipisahkan secara esensial. Ini tidak berbeda dengan yang tampak pada karya orang-orang sufi kita yang terkenal. $^{56}$

Dalam Islam, walawpun jarak yang terbentang antara manusia dengan Tuhan meluas sampai tak terhingga, jarak antara Tuhan dengan manusia sama sekali dihilangkan. Manusia digambarkan sebagai satu-satunya makhluk yang dalam penciptaan mempunyai jiwa ketuhanan, memikul tanggungjawab amanat Tuhan, dan dalam dirinya memiliki kualitas ketuhanan. $^{57}$

Dari serangkaian pendapat yang dinyatakan oleh empat aliran intelektual modern yang berpengaruh, Ali Sayia'ati sendiri memiliki rumusan sendiri mengenai manusia. manusia adalah mahluk yang mempunyai berbagai nilai bawaan pada alam material ini. Manusia dengan demikian memiliki esensi yang unik, dan ia hadir sebagai mahluk yang mulia. Manusia sendiri memiliki independensinya tersendiri, ia tidak dideterminasi oleh

\footnotetext{
${ }^{54}$ Ali Syari'ati, Humanisme antara Islam dan Madzhab Barat, Op. Cit. hlm. 46.

${ }^{55}$ Ibid. hlm. 47.

${ }^{56}$ Ali Syari' ati, Kritik Islam atas Marxisme dan Sesat-pikir Barat Lainnya, Op.Cit, hlm. 64.

${ }^{57}$ Ibid.
} 
materialistas, sehingga ia memiliki andil dalam menentukan nasibnya sendiri, dan ia bertanggung jawab atasnya. Namun, tanggung jawab ini hanya memiliki makna sejauh mengacu pada sebuah sistem nilai. ${ }^{58}$

Manusia dengan demikian adalah mahluk yang terus menerus mengejar cita-cita dan melakukan perubahan atas "apa yang ada" kepada "apa yang semestinya”, atau "apa yang kini ada" kepada "apa yang seharusnya ada” pada, diri sendiri, masyarakat serta alam material. ${ }^{59}$ Sepanjang manusia dikatakan sebagai makhluk yang mempunyai kemampuan kreatif, berarti dia bisa menguasai alam dan dirinya sendiri, dan dalam bentuknya yang seperti itu, maka melalui penciptaan keindahan, seni dan sastra, dia memberikan sesuatu yang belum pernah ada sebelumnya di alam ini; dan dengan industri, dia memberikan sesuatu yang tidak pernah diberikan alam kepadanya. ${ }^{60}$

Dalam sosok seperti itu pula, manusia adalah makhluk yang berpikir, dan dengan kemampuannya ini dia bisa mengenal alam dan posisi kemanusiaannya di dalam alam, di dalam masyarakat dan zaman. Kemudian, dengan jalan ini manusia mendorong eksistensi dirinya untuk melampaui dinding-dinding perwujudannya, dan rentangan pemikirannya - ke bawah menembus fenomena-fenomena inderawi, dan - ke atas - membubung tinggi dari daratan rendah alam fisik dan sempit, untuk sampai di sana - suatu tempat yang tak lagi ada sangkar, dan bila itu telah di lalui, manusia akan sampai pada ketinggian eksistensi yang tak terbatas. ${ }^{61}$

Kesimpulannya, manusia adalah makhluk yang memiliki esensi kesucian, yang dari situ diteteskan "kesakralan-kesakralan" yang membentuk ibadahnya menjadi penjelas eksistensi dirinya (tajalli) yang paling luhur, luar biasa dan supra-logik, dan di komunitasnya dia menciptakan nilai-nilai kemanusiaan. Yakni nilai-nilai yang melahirkan kegairahan, peribadatan, dan dampak dalam sejarah genera makhluk ini, dan yang merupakan modal spiritual-kemanusiaan yang semuanya patut dibanggakan. ${ }^{62}$ Nilai manusiawi adalah ide suci yang walawpun penerapannya mungkin berbeda, abadi dan

\footnotetext{
${ }^{58}$ Ibid. hlm. 73.

${ }^{59}$ Ali Syari'ati, Humanisme antara Islam dan Madzhab Barat, Op. Cit. hlm. 53.

${ }^{60}$ Ibid.

${ }^{61} \mathrm{Ibid}$.

${ }^{62} \mathrm{Ibid}$.
} 
absolut, dan mungkin hanya akan berubah apabila spesies manusia berubah atau binasa. ${ }^{63}$

b. Bagaimana konsep humanisme Islam menurut Ali Syari'ati

Ali Syari'ati menegaskan bahwa al-Qur'an memiliki konsep humanisme yang paling maju. Hal ini tergambar dalam kisah mengenai Nabi Adam. Namun, perlu dipahami bahwa kisah Nabi Adam ini mesti didekati dalam konteks filosofis dan bukan biologis. Ketika bicara tentang konteks biologis, al-Qur'an akan menggambarkan manusia dalam bahasa-bahasa ilmuilmu alam, seperti: janin, sperna, ilmu alam, dan lain semacamnya. Di dalam konteks filosofis, Adam merupakan gambaran prototipe manusia yang memiliki esensi dan spiritualitas. Adam adalah pencampuran dari anasir material dengan Ruh dari Allah. ${ }^{64}$

Manusia sebagai khalifah, oleh Allah, diciptakan dari tanah. ${ }^{65} \mathrm{Di}$ dalam al-Qur'an bahan dasar dari manusia itu sendiri disebutkan di dalam tiga ayat. Pertama, Al-Qur'an menggunakan istilah "lempung tembikar" (QS. 55:14); yakni lempung endapan kering. Kedua, "Kuciptakan manusia dari lempung berbau" (QS. 15:26), atau lempung busuk; ketiga, tin yang berarti lempung (QS. 6:2; 23:12). Singkatnya manusia ialah lempung yang ditiupkan ruh kepadanya oleh Allah. ${ }^{66}$

Lumpur itu sendiri merupakan simbol dari sebuah bahan atau entitas yang rendah. Sedangkan Allah adalah zat yang mulia dan sempurna. Manusia dalam hal ini adalah gabungan dari dua unsur tersebut. Ia merupakan campuran dari zat yang rendah dan juga zat yang luhur. Pada proses penciptaan manusia, Allah telah menghembuskan Ruh-Nya kepada lempung tadi, sehingga terwujudlah manusia. ${ }^{67}$

Manusia sendiri adalah mahluk yang dwidimensional, alias bukan unidimensional. Dimensi itu adalah dimensi lumpur yang rendah, dan ruh yang tinggi. Dimensi lumpur bisa membawa manusia pada titik terendahnya,

\footnotetext{
${ }^{63}$ Ali Syari'ati, Kritik Islam atas Marxisme dan Sesat-pikir Barat Lainnya, Op.Cit, hlm. 74.

${ }^{64}$ Ali Syari'ati, Paradigma Kaum Tertindas, (AL-HUDA: Jakarta, 2001), Cet. II, hlm. 79.

${ }^{65} \mathrm{Ibid}$. hlm. 64

${ }^{66} \mathrm{Ibid}$.

${ }^{67} \mathrm{Ibid}$.
} 
sedangkan dimensi ruhani akan membawanya pada titik tertinggi, yakni kepada asal muasalnya yakni Allah.. ${ }^{68}$

Sehabis dicipta oleh Allah, manusia pun diajari oleh Allah berbagai nama, meski kemudian para malaikat memprotes-Nya, "Kami diciptakan dari api tanpa asap, sedangkan manusia diciptakan dari lempung; kenapa Engkau melebihkannya dari kami?" Allah menimpali dengan jawaban, "Aku mengetahui apa yang tidak kalian ketahui; bersujudlah kepada makhluk-Ku yang bidimensional ini." Setiap malaikat kemudian diperintahkan oleh Allah untuk sujud pada manusia. ${ }^{69}$

Di sinilah gambaran Islam tentang kemuliaan manusia. Dibanding malaikat, manusia memang rendah, karena malaikat diciptakan dari cahaya, sedangkan manusia diciptakan dari tanah. Akan tetapi, dengan pengetahuan yang diberikan Allah kepadanyalah yang membuatnya memiliki status yang lebih tinggi, bahkan dibanding malaikat sekalipun. Alasannya, karena malaikat tidak memiliki kapasitas itu, malaikat tidak mengetahui namanama, sedang manusia mengetahuinya. ${ }^{70}$

Tentang kejadian wanita dari tulang rusuk pria merupakan hal yang perlu pula mendapat perhatian, setidak-tidaknya menurut terjemahan yang biasanya dari bahasa Arab. Tetapi menurut Ali Syari'ati terjemahan "tulang rusuk" itu keliru. Kata yang dimaksudkan, baik pada bahasa Arab atau Ibrani barangkali lebih tepat bila diterjemahkan sebagai "sifat, disposisi atau konstitusi". Maka dari itu hawa dicipta secara sama dengan pria. Oleh karena kekeliruan menterjemahkan kata itu dengan "tulang rusuk" maka beredarlah dongeng bahwa wanita dijadikan dari tulang rusuk kiri Adam, sehingga semua pria katanya mengalami kekurangan selembar tulang rusuk. ${ }^{71}$

Suatu ketika Allah pernah, dalam konteks cerita tentang manusia, memanggil seluruh ciptaan-Nya, lalu Ia berfirman "Aku hendak menawarkan suatu amanah kepadamu sekalian, bumi, langit, gunung, samudra dan hewan" (QS. 33:72). Semua mahluk enggan mengemban tanggung jawab tersebut. Hal ini

\footnotetext{
${ }^{68} \mathrm{Ibid}$

${ }^{69} \mathrm{Ibid}$. hlm. 65.

${ }^{70} \mathrm{Ibid}$

${ }^{71}$ Ibid.
} 
menunjukan betapa mulianya manusia. Ia ditunjuk sebagai khalifah, dan sebagai pengemban amanah. Yang dimaksud amanah di sini, bagi Jalaluddin Rumi, ialah kehendak bebasnya manusia. ${ }^{72}$

Dalam konteks filsafat manusia ini, Syari'ati membuat dua kesimpulan. Pertama, bahwa karena setiap manusia berasal dari asal yang sama, maka setiap manusia itu bersaudara dan sama. Sama sejauh berkaitan dengan konsep legal, dan bersaudara sejauh berkaitan dengan keseragaman sikap dan disposisi di antara manusia. ${ }^{73}$

Kedua, baik pria maupun wanita memiliki kedudukan yang sama, karena mereka berdua lahir dari satu sumber yang sama. ${ }^{74}$ Ketiga, kemuliaan manusia itu, dan yang membedakannya dengan malaikat adalah, terletak pada pengetahuannya. ${ }^{75}$

Kedudukan manusia yang mewujud di antara lumpur dan Allah ialah yang lebih penting menurut Ali Syari'ati. Dalam dua posisinya yang memiliki dua dimensi: rendah dan mulia, manusia pun dianugrahi kehendak bebas, yang juga sepaket dengan tanggung jawab. Dalam Islam, manusia sendiri diberkahi oleh tanggungjawab yang tidak hanya berkaitan dengan dirinya, namun berkaitan denga seluruh alam. ${ }^{76}$ Berkat pelajaran primordial dari Allah ini manusia bisa mencapai semua kebenaran yang terdapat dalam dunia, dan ini merupakan tanggungjawab besar manusia yang kedua. Manusia harus membentuk nasibnya dengan tangannya sendiri, begitu pula manusia perseorangan bertanggungjawab atas nasibnya sendiri. "Untuk kalian hasil usaha kalian dan untuk mereka hasil usaha mereka" (Q.S. 2:134). Nasib peradaban-peradaban di masa lampau tidak lebih dan tidak kurang dari kadar usaha mereka, sedangkan nasib kita akan sesuai persis dengan kadar usaha kita membentuknya dengan tangan kita sendiri. Demikianlah, karena kehendak bebas yang dimilikinya, manusia mempunyai tanggungjawab yang besar kepada Allah. ${ }^{77}$

\footnotetext{
${ }^{72}$ Ibid. hlm. 66.

${ }^{73}$ Ibid. hlm. 67.

${ }^{74}$ Ibid.

${ }^{75}$ Ibid.

${ }^{76}$ Ibid.

${ }^{77}$ Ibid. hlm. 68.
} 
Di dalam Islam sendiri, disebutkan bahwa manusia yang berdwidimensional seringkali diganggu oleh mahluk yang dikenal dengan syetan. Namun, syetan ini bukan oposisi bagi Allah. Karena Allah adalah satu-satunya raja di alam semesta. Syetan di sini adalah oposisi bagi manusia, ia berkehendak untuk menyesatkan manusia dari jalan ruhani menuju Allah. ${ }^{78}$

Dalam filsafat Islam, tentang manusia dijelaskan bahwa manusia memiliki daya untuk mengarahkan kecenderungan kontradiktif yang ada dalam dirinya. Hanya dengan demikianlah manusia mampu memelihara keseimbangannya. Agama itu ialah Islam. ${ }^{79}$

Tugas intelektual dewasa ini adalah mengenali Islam. Karena Islam hadir sebagai pembangkit kemanusiaan, dan juga ia merupakan agama yang mampu memberi jalur bagi masa depan umat manusia. Para intelektual harus melihat ini sebagai tugas yang tidak dapat di sisihkan. Mereka perlu melihat agama ini dengan seksama dan melihat tokoh-tokoh terkemukanya dari bidang studi apa saja. Karena Islam mempunyai banyak dimensi dan manifestasi yang berbeda-beda, siapa saja dapat menemukan bidang-bidang baru dan rinci sesuai dengan bidang khususnya. ${ }^{80}$

Menurut Ali Syari'ati, ada cara yang berbeda-beda untuk mengenal Islam. ${ }^{81}$ Pertama-tama, Tuhan Islam ialah Tuhan yang dwidimensional. Tuhan memiliki aspek Yehovah dan Isa: memiliki sifat yang keras dan sifat yang lembut. ${ }^{82}$

Mengenai Al-Qur'an, Al-Qur'an di satu pihak mengatur kehidupan, pembangunan, kesejahteraan, perlawanan terhadap musuh dan anasir negatif, sedang di pihak lain kitab itu pun memberi guide untuk memperhalus, menyempurnakan dan menyucikan jiwa, juga menyempurnakan akhlak perorangan. ${ }^{83}$

\footnotetext{
${ }^{78}$ Ibid.

${ }^{79}$ Ibid. hlm. 69.

${ }^{80}$ Ali Syari'ati, Islam Agama "Protes", (PUSTAKA HIDAYAH: Jakarta, 1993), hlm. 93-94

${ }^{81}$ Ibid. hlm. 93

${ }^{82}$ Ali Syari'ati, Paradigma Kaum Tertindas, Op.Cit. hlm. 69

${ }^{83}$ Ibid.
} 
Begitu pula dalam pribadi Rasul Islam terdapat dua aspek yang kontras. Yang untuk orang lain akan merupakan aspek-aspek yang berlawanan, tetapi dalam diri beliau terjalin menjadi satu paduan semangat. Beliau senantiasa terlibat dalam perjuangan politik menghadapi lawan dan serba kekuatan yang merusak dalam masyarakat. Beliau mencurahkan perhatian untuk membangun suatu masyarakat dan peradaban baru, sementara itu sekaligus beliau adalah seorang manusia shalat, taqwa dan ibadah, pembimbing umat kepada hidayah. ${ }^{84}$

Dan kemudian ketiga orang yang menerima bimbingannya - 'Ali, Abu Dzarr dan Salman - adalah contoh-contoh utama manusia bidimensional. Mereka adalah manusia-manusia politik dan perang. Mereka selalu terlibat dalam usaha meningkatkan kehidupan mereka. Tetapi mereka tidak pernah absen menghadiri perbincangan-perbincangan dan peng-kajian ilmiah. Sementara itu mereka merupakan manusia-manusia taqwa dan mukhlis, tidak kalah dari para biarawan dan para tokoh kebatinan Timur yang pernah dikenal sejarah. ${ }^{85}$ Inilah Islam. Lebih dari agama mana pun, Islam adalah agama pembacaan buku, agama aksi, agama pemikiran dan cinta. ${ }^{86}$

Kesimpulan Ali Syari'ati: Manusia di dalam islam bukanlah mahluk yang rendah. Ia adalah mahluk yang mulia, alasanya karena manusia merupakan pengemban amanah langsung dari Tuhan. Ia juga merupakan khalifah bagi alam semesta ini. Manusia pun hadir sebagai mahluk yang berdwidimensional, sekaligus bertanggung jawab atas keseimbangannya sendiri. Kemudian, manusia pun pada dasarnya perlu sebuah agama, namun agama yang dimaksud adalah agama yang berorientasi pada dua dunia, yakni alam material dan alam akhirat. ${ }^{87}$

\footnotetext{
${ }^{84}$ Ibid. hlm. 69-70.

${ }^{85}$ Ibid. hlm. 70.

${ }^{86}$ Ali Syari'ati, Fatimah: The Greatest Women in Islamic History, (Tahira: Bandung, 2008), hlm. 28

${ }^{87}$ Ali Syari'ati, Paradigma Kaum Tertindas, Op.Cit. hlm. 70
} 


\section{B. Simpulan}

Penelitian ini menghasilkan dua kesimpulan utama yang koheren dengan dua tujuan penelitian yang telah di gariskan di awal penelitian.

Pertama, bagi Ali Syari'ati humanism adalah paham yang menegaskan kemuliaan manusia, yang mana kemuliaan itu didasarkan pada pemenuhan kebutuhan pokok manusia.

Manusia bagi Syariati, adalah mahluk yang memiliki esensi di alam fisik ini. Kemudian, manusia juga memiliki kehendak yang membawanya bisa memiliki andil untuk menentukan nasibnya sendiri dan tentu saja bertanggung jawab atasnya. Namun, kehendak dan tanggung jawabnya ini dadasarkan pada suatu nilai.

Kedua, Syari'ati menegaskan bahwa Islam memiliki sebuah humanism yang lebih luhur dan mulia. Kemuliaan itu sendiri digambarkan sebagaimana di dalam al-Qur'an pada proses penciptaan Adam. Adam adalah prototipe manusia. Manusia sendiri menjadi mulia, karena ia diberi Ruh dari Allah. Selain Ruh, manusia pun diberi pengetahuan, yang mana membuatnya lebih mulia dibanding malaikat. Dengan kemuliaan ini kemudian, manusia diberi agama sebagai sebuah petunjuk yang berorientasi pada dunia ini dan dunia akhirat. Agama yang dimaksud oleh Syari'ati di sini adalah agama Islam.[] 


\section{DAFTAR PUSTAKA}

Al-Ghazali, Imam,Dibalik Tabir Kematian, Khatulistiwa Press, Jakarta 2009.

Al-Walid,Dr.Kholid, perjalanan Jiwa menuju Akhirat, Sadra Press, 2012.

Arifin Abbas, Zainal, Perkembangan Pikiranterhadap Agama 1, pustaka alHusna, Jakarta 1984.

Ar-Razi, Imam, RUH dan JIWA, Risalah Gusti, Surabaya 2000.

Bagus, Lorens, Kamus Filsafat, Jakarta: Gramedia 2002.

Bakker,Anton dan Charris Zubair, Ahmad, Metode Penelitian Filsafat, Yogyakarta:Kanisius 1992.

Basri, Hasan dan Mufti, Zainal, Filsafat Islam Sejak Klasik Sampai Modern, Bandung:insan Mandiri, 2009.

Daudy, Ahmad, Kuliah Filsafat Islam, Bulan Bintang, Jakarta, 1985.

Hidayat, Komaruddin, Psikologi kematian, Hikmah, Jakarta, 2005.

Hossein Nasr, Seyyed, Ensiklopedi Tematis Spiritual Islam, Bandung: Mizan, 2003.

, Seyyed dan Leaman, Oliver, Ensiklopedi Tematis Filsafat Islam 1, Bandung :Mizan, 2003.

Husein Thabathaba'I, Muhammad, Kehidupan Setelah Mati, Mizan, Bandung 2013. , Bidayah Al-Hikmah, Tehran : Dar Al-Fikr, 1387.

Madjid, Nurcholish, Khazanah Intelektual Islam, Bulan Bintang, Jakarta 1984. Nasution, Harun, Falsafat Agama, Bulan Bintang, Jakarta, 1973.

Teologi Islam Aliran-Aliran Sejarah Analisa Perbandingan, Jakarta: UI-Press, 1986.

Falsafat dan Mistisisme dalam Islam, Bulan Bintang, Jakarta, 2006.

Rahman, Fazlur, Tema pokok Al-qur'an, Pustaka, Bandung, 1983.

Sina, Ibn, Al-Mabda' wal-Ma'ad, Tehran: Donesgoh Tehran, 1363. Al-Isyarat wa al-Tanbihat, Qom: Nashr al-Balaghah, 1375.

Ahwal An-nafs (diterjemahkan oleh Irwan Kurniawan, Bandung:Pustaka Hidayah, 2009.

Subhani, Ja'far, Al-Ilahiyat, (Qom: Muasasa Nasr al-Islami, 1416).

Supriyadi, Dedi, Pengantar Filsafat Islam, Bandung:Pustaka setia, 2010. 